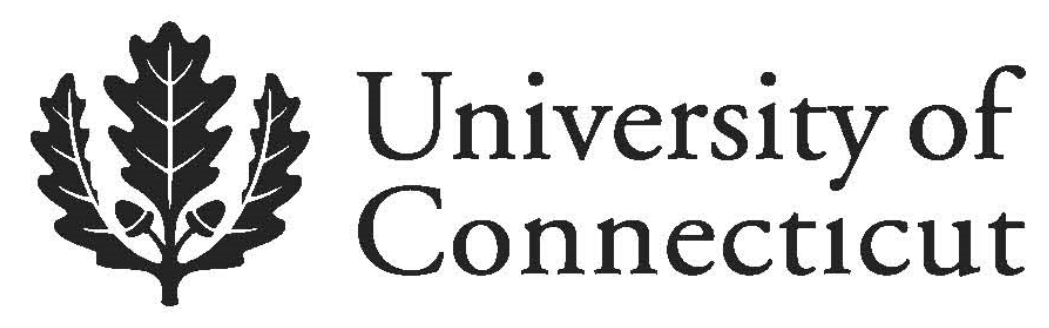

Department of Economics Working Paper Series

\title{
"Piggyback" Lawsuits and Deterrence: Can Frivolous Litigation Improve Welfare?
}

Thomas J. Miceli

University of Connecticut

Michael P. Stone

Quinnipiac University

Working Paper 2013-16

July 2013

365 Fairfield Way, Unit 1063

Storrs, CT 06269-1063

Phone: (860) 486-3022

Fax: (860) 486-4463

http://www.econ.uconn.edu/

This working paper is indexed on RePEc, http://repec.org 


\title{
"Piggyback" Lawsuits and Deterrence: Can Frivolous Litigation Improve Welfare?
}

\author{
by
}

\author{
Thomas J. Miceli* and Michael P. Stone**
}

\begin{abstract}
Previous literature on frivolous lawsuits has focused on litigation costs and the optimal settlement-trial decision of defendants, but has not examined how they affect deterrence. This paper examines whether there are circumstances under which frivolous suits might actually increase deterrence, and thereby possibly improve welfare. The reason this is possible is that in a costly legal system, injurers will generally be underdeterred because they will ignore the litigation costs of plaintiffs. The fact that some uninjured plaintiffs will succeed in obtaining settlements may therefore affect the care and activity choices of injurers in a socially valuable way.
\end{abstract}

JEL codes: K13, K41

Key words: Frivolous lawsuits, care, activity level, deterrence

July 2013

*Professor, Department of Economics, University of Connecticut, Storrs, CT 06269; Ph: (860) 486-5810; Fax: (860) 486-4463; e-mail: Thomas.Miceli@UConn.edu.

**Assistant Professor, Department of Economics, Quinnipiac University, Hamden, CT 06518; Ph: (860) 874-4507; e-mail: Michael.Stone@ Quinnipiac.edu.

Acknowledgement: We acknowledge the helpful comments of participants at the $23^{\text {rd }}$ Annual Meeting of the American Law and Economics Association, May 2013. 


\section{"Piggyback" Lawsuits and Deterrence: Can Frivolous Litigation Improve Welfare?}

\section{Introduction}

Previous economic literature on frivolous (or nuisance) suits has focused on their impact on litigation costs and the settlement trial-decision of defendants, ${ }^{1}$ but has not examined how they affect deterrence. This paper examines whether there are circumstances under which frivolous suits might actually increase deterrence, and thereby possibly improve welfare. The reason for this possibility is that in a costly legal system, injurers will generally be underdeterred - first, because they will ignore the litigation costs of plaintiffs, and second, because filing costs will prevent some legitimately injured victims from filing suit, thereby insulating injurers from a portion of the harm they caused. ${ }^{2}$ Since some uninjured plaintiffs will file suit, frivolous lawsuits may enhance deterrence in a socially valuable way.

Assessing the impact of frivolous lawsuits is complicated, however, by ambiguity regarding what exactly constitutes a frivolous suit. In the legal profession, personal injury lawyers would likely argue that frivolous suits are rarely initiated under contingency fee arrangements because law firms will not expect to earn profits by accepting them. ${ }^{3}$ In contrast, some politicians have argued that frivolous suits pose a serious threat to the efficient operation of the civil justice system. And the general public's perceptions of the tort system are often colored by high profile but unrepresentative cases, like the infamous McDonald's coffee case. ${ }^{4}$

\footnotetext{
${ }^{1}$ See, for example, Rosenberg and Shavell (1985), Bebchuk (1988, 1996), Katz (1990) Miceli (1993, 1994) and Bone (1997). For surveys see Bebchuk (1998) and Rasmusen (1998).

${ }^{2}$ See, for example, Shavell (1982), Hylton (1990a), Polinsky and Rubinfeld (1988), and Ordover (1978).

${ }^{3}$ But see Miceli (1994).

${ }^{4}$ See Liebeck v. McDonald's Restaurants, Docket No. D-202 CV-93-02419, 1995 WL 360309 (Bernalillo County, N.M. Dist. Ct. August 18, 1994).
} 
Furthermore, legal definitions are not of much help in formalizing the notion of a frivolous suit. The U.S. Supreme Court, for example, has defined a suit to be frivolous when it "lacks an arguable basis either in law or in fact." Similarly, the Restatement (Third) of Law Governing Lawyers (2000) states that "[a] frivolous position is one that a lawyer of ordinary competence would recognize as so lacking in merit that there is no substantial possibility that a tribunal would accept it." In the extreme, one court has even stated that the term "frivolous" is "incapable of precise determination.",

Economists have shown that in a world of asymmetric information, suits without merit can succeed in receiving settlements (Bebchuk, 1988; Katz, 1990), but the literature to this point has not been explicit regarding the source of frivolous plaintiffs. It is generally assumed that a defendant faces an exogenous supply of potentially frivolous suits which consist of uninjured or only slightly injured plaintiffs. These plaintiffs are willing to file suit in hopes of obtaining a settlement, but would never be willing to take their cases to trial if the defendant refused to offer a positive settlement amount. ${ }^{8}$ The focus of these studies is the defendants' optimal strategy when faced with frivolous suits—specifically, should defendants pay them off as part of a policy of settling all cases, or should they refuse to settle and risk incurring trial costs if the plaintiff turns out to be legitimate? Apart from the choice between these two strategies, defendants are viewed as essentially defenseless against frivolous cases-they are, in effect, a fixed cost of engaging in a risky activity.

In reality, however, defendants can potentially affect the incidence of frivolous suits by their choice of how frequently to engage in risky activity. In the extreme, they can presumably

\footnotetext{
${ }^{5}$ Nietzke v. Williams, 490 U.S. 319, 325 (1989).

${ }^{6}$ See $\$ 110$, comment d.

${ }^{7}$ de Vaux v. Westwood Baptist Church, 953 So. 2d 677, 683 (Fla. Dist. Ct. App. 1st Dist. 2007).

${ }^{8}$ Some authors distinguish between plaintiffs who are uninjured and those who are injured but would be unwilling to incur the costs of trial (the latter referred to as "negative expected value" (NEV) suits). We do not distinguish the two here.
} 
avoid frivolous suits altogether by simply shutting down. This reflects the idea that frivolous plaintiffs "piggyback" on legitimate suits filed against individuals or businesses whose ordinary activity results in some accidents. Based on this logic, we define piggyback suits as consisting of those cases brought against a defendant engaged in a risky activity where the plaintiffs are: (1) actual accident victims whose injuries were caused by someone other than the defendant; (2) actual accident victims whose injuries were caused by "nature"; or (3) uninjured plaintiffs. Although these suits contain a mixture of truly injured and uninjured plaintiffs, as a matter of law they are all "frivolous" in the sense that, even under a rule of strict liability, the injurer would not be held liable for their damages in court. We assume, therefore, that the court is able to perfectly discern which plaintiffs are legitimately entitled to compensation by the defendant and which are not. At the time a lawsuit is filed, however, the defendant cannot make this determination, though we will assume that he knows the frequency of piggyback suits among his population of plaintiffs. ${ }^{9}$

The analysis of the disposition of lawsuits in the presence of frivolous suits (the settlement-trial decision) follows the asymmetric information approach of Katz (1990), but we go beyond his model to examine how the resulting equilibrium affects the prior decisions of the defendant (injurer). In particular, we ask how the threat of piggyback suits affects his decisions regarding how often to engage in the activity in question, and how careful to be when so engaged. The answers to these questions will allow us to address the question posed in the title: namely, are frivolous suits detrimental to social welfare as is conventionally believed, or might there be some conditions under which their presence actually creates incentives for injurers engaged in risky activities to make more efficient decisions, thereby increasing welfare?

\footnotetext{
${ }^{9}$ The analysis here differs from Shavell's (1985) model of uncertainty over causation in the sense that he supposes that the court is not able to distinguish among the possible causes of some accidents.
} 
The remainder of the paper is organized as follows. Section 2 describes the basic model, and Section 3 derives the outcome under certainty; that is, where defendants can perfectly distinguish between legitimate and frivolous plaintiffs. Section 4 turns to the outcome under uncertainty and derives the conditions under which frivolous suits can succeed in obtaining settlements. It then shows the impact of the resulting equilibria on the care and activity choices of those individuals or businesses engaged in risky activities. Section 5 addresses the welfare question by showing specifically how the presence of frivolous suits affects the expected social value of the risky activity. Section 6 pursues some extensions of the basic model, and finally, Section 7 concludes.

\section{The Model}

The formal model will make use of the following notation:

$z=$ injurer's activity level, reflecting how frequently he engages in a risky activity;

$V(z)=$ injurer's gross value of engaging in the activity, $V^{\prime}>0, V^{\prime \prime}<0$;

$x=$ injurer's expenditure on care, per unit of the activity;

$p(x)=$ probability of an accident caused by the injurer, measured per unit of the activity, where $p^{\prime}<0, p^{\prime \prime}>0$;

$q=$ probability of a potential piggyback suit per unit of the activity;

$L=$ dollar loss suffered by a legitimate accident victim;

$k=$ victim's cost of filing suit;

$C_{p}, C_{d}=$ cost of a trial to the plaintiff (victim) and defendant (injurer).

Additional notation will be defined as needed. 
The sequence of events is as follows. First the injurer chooses his activity level, which determines the frequency of accidents truly caused by his activity, as well as the potential number of piggyback suits. If active (i.e., if $z>0$ ), the injurer can affect the frequency of legitimate suits by his choice of care as in standard accident models. The injurer's care does not, however, affect the frequency of piggyback suits, which is assumed to be fixed once his activity level is set.

After the injurer has chosen his activity and care levels, the number of legitimate and potential piggyback plaintiffs per unit of injurer activity is determined according to the probabilities $p(x)$ and $q$, respectively. Plaintiffs of both types then must decide whether or not to file suit at cost $k$. Once a plaintiff files, the injurer (now defendant) makes a take-it-or-leave-it settlement offer, $S \geq 0$, which the plaintiff either accepts, in which case the game ends, or rejects, in which case the plaintiff either drops the suit or the parties go to trial. At trial, the court determines with certainty whether or not the plaintiff is truly injured, and if so, whether that injury was caused by the defendant. Assuming a rule of strict liability, ${ }^{10}$ the court awards damages of $L$ to plaintiffs whose injuries were caused by the defendant, and zero to those who either are uninjured or whose injuries were caused by some other source. In all cases, plaintiffs and defendants incur trial costs of $C_{p}$ and $C_{d}$, respectively. ${ }^{11}$

We assume that the fixed level of damages, $L$, is large enough that plaintiffs who were truly injured by the defendant (and hence entitled to compensation) will find it profitable to file suit, and, if necessary, go to trial. That is,

$$
L>C_{p}+k \text {. }
$$

\footnotetext{
${ }^{10}$ We consider a negligence rule in Section 6.1 below.

${ }^{11}$ In Section 6.2 we consider fee shifting rules.
} 
It follows from (1) that if a defendant knows with certainty that a plaintiff has a legitimate case, he will offer $S=L-C_{p}>0$, which is the lowest settlement offer that the plaintiff will accept rather than go to trial, assuming that when indifferent, the plaintiff prefers settlement to trial. Note that this settlement offer is independent of the plaintiff's filing cost because that cost is sunk once settlement negotiations commence. However, (1) ensures that legitimate plaintiffs, if they anticipate settling for this amount, will find it profitable to file suit since $S>k$.

As for potential piggyback plaintiffs, the defendant would obviously offer them $S=0$ if he could observe their true type, and anticipating this, no such plaintiffs would ever file suit. When the plaintiff cannot distinguish legitimate from piggyback plaintiffs, however, he faces a dilemma: if he offers $S=L-C_{p}$, he avoids trial with legitimate plaintiffs, but all potential piggyback plaintiffs will file suit, thus raising his settlement costs. Alternatively, if he offers $S=0$, this will discourage piggyback plaintiffs from filing but will require him to go to trial with all legitimate plaintiffs at a cost of $L+C_{d}$ per suit, which is obviously higher than $L-C_{p} .{ }^{12}$ The defendant's optimal strategy in this situation is examined in detail below. First, however, we derive his optimal behavior under certainty as a benchmark.

\section{The Outcome Under Certainty}

This section derives the outcome of the model when the injurer can perfectly distinguish between legitimate and piggyback suits. As usual, we derive the defendant's optimal behavior in reverse sequence of time. Thus, beginning with the settlement-trial decision, recall that the injurer-defendant will offer $S=L-C_{p}$ to legitimate plaintiffs and $S=0$ to piggyback plaintiffs,

\footnotetext{
${ }^{12}$ Note that it would never pay the defendant to offer an amount between 0 and $L-C_{p}$ because legitimate plaintiffs would reject it, and there is no reason to offer a positive amount to piggyback plaintiffs. Similarly, there is no reason to offer more than $L-C_{p}$ since we have assumed that legitimate plaintiffs will accept this lesser amount.
} 
thereby inducing only legitimate plaintiffs to sue, and then to settle. The injurer's expected value of engaging in the activity in question can therefore be written as

$$
V(z)-z\left[x+p(x)\left(L-C_{p}\right)\right]
$$

where the expression in square brackets is his expected liability-plus-care costs per unit of activity. Note that $q$ does not enter into this expression because all piggyback plaintiffs are deterred from filing suit by the defendant's credible threat to offer them a zero settlement amount.

Maximizing (2) with respect to $x$ and $z$ yields the following first-order conditions for care and activity:

$$
\begin{aligned}
& 1+p^{\prime}(x)\left(L-C_{p}\right)=0, \\
& V^{\prime}(z)-\left[x+p(x)\left(L-C_{p}\right)\right]=0 .
\end{aligned}
$$

Let $x_{c}$ and $z_{c}$ denote the solutions to (3) and (4), respectively. Note that given linearity of costs in $z$, the injurer's optimal care is independent of his activity level. (In other words, optimal care does not depend on the scale of the defendant's activity.) These solutions will serve as a benchmark for the equilibrium under uncertainty to be examined in the next section.

\section{Equilibrium Under Uncertainty}

Consider now the equilibrium when the injurer-defendant is unable to distinguish between legitimate and piggyback plaintiffs. As above, we derive the equilibrium in reverse sequence, beginning with the settlement-trial decision, and then turning to the injurer's care and activity choices.

\subsection{Settlement-Trial Outcome}


In order to examine the settlement-trial decision in this case, which closely follows the approach in Katz (1990), we first need to think carefully about the strategies of plaintiffs and defendants at that stage. As noted above, legitimate plaintiffs will file suit with certainty regardless of what settlement offer the defendant is expected to make because they are willing to go to trial if the defendant offers zero. But, piggyback plaintiffs will only file suit if they expect a sufficiently high settlement offer. Thus, the behavior of piggyback plaintiffs depends on their expectation of what amount defendants will offer as a settlement. Similarly, the optimal strategy of defendants depends on what they expect piggyback plaintiffs to do at the filing stage. To derive these strategic decisions, we define $\varphi$ as the probability that a piggyback plaintiff files suit, and $\theta$ as the probability that the defendant offers $S=L-C_{p}$ rather than $S=0$. Note that in the certainty model above, $\varphi=0$ and $\theta=1$ in equilibrium, but this outcome will not be possible under uncertainty.

Consider first the defendant's strategy once a suit is filed. His decision about whether to offer $S=L-C_{p}$ or 0 will depend on his estimate of the probability that the plaintiff has a legitimate or a piggyback claim. Using Bayes' rule, he calculates the following probability that the claim is legitimate:

$$
\hat{p}(x)=\frac{p(x)}{p(x)+\varphi q}
$$

which depends on his prior choice of care, $x$. Note that this expression ranges from 1 when $\varphi=0$ to $p(x) /(p(x)+q)$ when $\varphi=1$. If the defendant offers $S=L-C_{p}$, all plaintiffs will accept, and his costs will be $L-C_{p}$, whereas if he offers 0 , only legitimate plaintiffs will go to trial, and his costs will be $\hat{p}(x)\left(L+C_{d}\right)$. Thus, if $\hat{p}(x)>\left(L-C_{p}\right) /\left(L+C_{d}\right)$, the defendant will offer $S=L-C_{p}$ (i.e., $\left.\theta=1\right)$; if $\hat{p}(x)<\left(L-C_{p}\right) /\left(L+C_{d}\right)$, the defendant will offer $S=0$ (i.e., $\left.\theta=0\right)$; and if $\hat{p}(x)=\left(L-C_{p}\right) /\left(L+C_{d}\right)$, the defendant will be indifferent between the two offers (i.e., $0 \leq \theta \leq 1)$, where $0<\left(L-C_{p}\right) /\left(L+C_{d}\right)<1$. 
Now suppose that $\varphi=1$, meaning that all potential piggyback plaintiffs file suit. Then, if

$$
\frac{p(x)}{p(x)+q}>\frac{L-C_{p}}{L+C_{d}}
$$

the defendant will offer $S=L-C_{p}$ and settle with all plaintiffs $(\theta=1)$, even though he knows that a fraction are piggyback suits. And because piggyback suits in this case are profitable by (1), all potential piggybackers will file, meaning that $\varphi=1$ is consistent with the defendant's optimal behavior. Thus, when (6) holds, the equilibrium of the settlement-trial game involves $\varphi=\theta=1$, with all cases settling. We will refer to this as a Type 1 equilibrium.

Alternatively, suppose that

$$
\frac{p(x)}{p(x)+q}<\frac{L-C_{p}}{L+C_{d}}
$$

Now if $\varphi=1, S=0$ is the cheaper strategy for the defendant $(\theta=0)$, but then the expected return from filing a piggyback suit is negative, which implies that $\varphi=0$. Thus, $\varphi=1$ and $\theta=0$ cannot be an equilibrium. Conversely, if $\varphi=0$, the defendant's optimal strategy is to offer $S=L-C_{p}(\theta=1)$ because $\hat{p}(x)=1$, but then piggyback suits become profitable, and $\varphi=1$. Thus, $\varphi=0$ and $\theta=1$ also cannot be an equilibrium. In general, there is no pure strategy equilibrium when (7) holds.

There is, however, a mixed strategy equilibrium in which the defendant is indifferent between offering $S=L-C_{p}$ and 0 , and piggyback plaintiffs are indifferent between filing and not filing suit. Indifference for the defendant requires that $\hat{p}(x)\left(L+C_{d}\right)=L-C_{p}$, which, using (5), implies that

$$
\varphi^{*}=\frac{p(x)\left(C_{p}+C_{d}\right)}{q\left(L-C_{p}\right)}
$$

which is between 0 and 1 when (7) holds. Indifference for piggyback plaintiffs requires that $\theta\left(L-C_{p}\right)-k=0$, or that

$$
\theta^{*}=\frac{k}{L-C_{p}}
$$


which is between 0 and 1 by (1). In this mixed strategy equilibrium, which we will refer to as a Type 2 equilibrium, all legitimate plaintiffs sue, and a fraction $\varphi^{*}$ of potential piggyback plaintiffs file, while the defendant settles a fraction $\theta^{*}$ of cases and takes the remainder to trial.

We can now compute the defendant's expected litigation costs from the settlement-trial game. In the Type 1 (pure strategy) equilibrium, which is relevant when (6) holds, recall that all potential piggyback plaintiffs file suit, and all cases settle for $L-C_{p}$. Thus, at the point where he makes his care and activity choices, the defendant's expected care-plus-settlement costs are given by

$$
T C_{1}=x+[p(x)+q]\left(L-C_{p}\right) .
$$

In the Type 2 (mixed strategy) equilibrium, which is relevant when (7) holds, the calculation is somewhat more complicated. The total number of legitimate suits filed is $p(x)$, and the total number of piggyback suits is $q \varphi^{*}$. A fraction $\theta^{*}$ of the legitimate suits settle and the remainder go to trial, while a fraction $\theta^{*}$ of the piggyback suits settle and the remainder are dropped. The resulting expression for total costs is

$$
T C_{2}=x+p(x)\left[\theta^{*}\left(L-C_{p}\right)+\left(1-\theta^{*}\right)\left(L+C_{d}\right)\right]+q \varphi^{*} \theta^{*}\left(L-C_{p}\right) .
$$

After substituting from (8) and (9) this simplifies to

$$
T C_{2}=x+p(x)\left(L+C_{d}\right) .
$$

Thus, total expected litigation costs in the mixed strategy equilibrium turn out to be equal to the cost the defendant would incur if only legitimate cases were filed but all went to trial. Comparing (10) and (12) verifies that, for any $x, T C_{1}<T C_{2}$ in the range where the Type 1 equilibrium obtains (i.e., when (6) holds), while the reverse is true when the Type 2 equilibrium obtains (i.e., when (7) holds). Thus, the defendant's optimal strategy is indeed cost-minimizing.

\subsection{Care and Activity Choices}


We now turn to the derivation of the injurer's optimal care and activity choices. The problem can be formally stated as follows:

$$
\begin{aligned}
V(z)-z\left[x+(p(x)+q)\left(L-C_{p}\right)\right], & & \frac{p(x)}{p(x)+q}>\frac{L-C_{p}}{L+C_{d}} \\
\max _{x, z} & & \frac{p(x)}{p(x)+q}<\frac{L-C_{p}}{L+C_{d}},
\end{aligned}
$$

where the first line is relevant for a Type 1 equilibrium, and the second line is relevant for a Type 2 equilibrium. In solving this problem we will make the following assumption:

$$
\frac{p(0)}{p(0)+q}>\frac{L-C_{p}}{L+C_{d}}
$$

This implies that when $x=0$, total litigation costs are lower under a Type 1 equilibrium. In other words, if the injurer takes no care, which means that the probability of a legitimate accident is $p(0)$, his optimal strategy will be to settle with all plaintiffs. This assumption will ensure that both types of equilibria can emerge as the solution to (13).

Given (14), and noting that $p(x) /(p(x)+q)$ is decreasing in $x$ (given $p^{\prime}<0$ ), we define $\hat{x}(q)>0$ to be the solution to

$$
\frac{p(x)}{p(x)+q}=\frac{L-C_{p}}{L+C_{d}}
$$

For $x<\hat{x}(q)$, expected litigation costs are lower in the Type 1 equilibrium, whereas for $x>\hat{x}(q)$, expected litigation costs are lower in the Type 2 equilibrium. It follows that (13) can be rewritten as

$$
\begin{array}{cc}
V(z)-z\left[x+(p(x)+q)\left(L-C_{p}\right)\right], & x<\hat{x}(q) \\
\max _{x, z} V(z)-z\left[x+p(x)\left(L+C_{d}\right)\right], & x>\hat{x}(q) .
\end{array}
$$

Intuitively, as the injurer invests in greater care, the number of potential piggyback suits (which is fixed) increases relative to the number of legitimate suits. Thus, the injurer becomes less 
inclined to settle all cases, and the equilibrium switches from a Type 1 to a Type 2, with the switching point being at $x=\hat{x}(q) .^{13}$

Consider first the injurer's optimal care choice, which as shown in the certainty model is independent of his activity level. As a preliminary step, define $x_{1}^{*}$ as the solution to

$$
1+p^{\prime}(x)\left(L-C_{p}\right)=0
$$

and $x_{2}^{*}$ as the solution to

$$
1+p^{\prime}(x)\left(L+C_{d}\right)=0 .
$$

Thus, $x_{1} *$ is the injurer's cost-minimizing care level in a Type 1 equilibrium, and $x_{2} *$ is his costminimizing care level in a Type 2 equilibrium, where $x_{1} *<x_{2}{ }^{*}$, given that the injurer's expected litigation costs are higher in a Type 2 equilibrium. (Although the injurer faces more overall suits in a Type 1 equilibrium, the cost of settling piggyback suits is essentially a fixed cost since their frequency is unaffected by the injurer's care.) The care choice that solves (16) will therefore either be $x_{1}^{*}$ or $x_{2}{ }^{*}$, depending on which type of equilibrium of the settlement game involves lower costs. Three cases are possible.

Case 1: $x_{1} *<x_{2} *<\hat{x}(q)$. In this case, the injurer's overall costs (as measured per unit of activity) are minimized at $x_{1}^{*}$, and the equilibrium is Type 1 . Thus, the injurer settles with all plaintiffs, and all potential piggyback suits are filed. This outcome is illustrated in Figure 1, where the relevant portions of the cost curves are darkened.

[Figure 1 here]

Case 2: $x_{1} *<\hat{x}(q)<x_{2}{ }^{*}$. In this case, two outcomes are possible: one involving a Type 1 equilibrium with the injurer choosing care of $x_{1} *$, and the other involving a Type 2 equilibrium with the injurer choosing care of $x_{2} *$. Which of these obtains depends on which has lower

\footnotetext{
${ }^{13}$ It should now be apparent why the assumption in (14) was needed. If (14) does not hold, then even when the injurer takes the lowest possible care-meaning that the relative number of legitimate suits is the highest possiblethe injurer will prefer a Type 2 equilibrium, and as a result, the Type 1 equilibrium will never be optimal.
} 
expected accident costs, given the optimal care choice. The first outcome is illustrated in Figure 2 (Case 2 (a)), and the second is illustrated in Figure 3 (Case 2 (b)).

[Figures 2 and 3 here]

Case 3: $\hat{x}(q)<x_{1} *<x_{2} *$. In this final case, illustrated in Figure 4, the injurer's costs are minimized at $x_{2}^{*}$ and the equilibrium is Type 2 .

[Figure 4 here]

The injurer's optimal activity level depends on which type of equilibrium obtains. If it is of Type 1, the injurer will choose $z$ to solve

$$
V^{\prime}(z)-\left[x_{1}^{*}+\left(p\left(x_{1}^{*}\right)+q\right)\left(L-C_{p}\right)\right]=0 .
$$

Denote the solution to this condition $z_{1} *$. Alternatively, if it is a Type 2 equilibrium, the injurer will choose $z$ to solve

$$
V^{\prime}(z)-\left[x_{2}^{*}+p\left(x_{2}^{*}\right)\left(L+C_{d}\right)\right]=0 .
$$

Denote the solution to this condition $z_{2}^{*}$. We have already seen that $x_{1} *<x_{2} *$, reflecting the higher care-sensitive litigation costs in the Type 2 equilibrium. In contrast, $z_{1} * \frac{\geq}{<} z_{2} *$. Although the Type 2 equilibrium involves higher litigation costs due to the fact that some cases go to trial, the Type 1 equilibrium involves more overall suits because of the larger percentage of piggyback suits that are filed. As noted, the number of piggyback suits is not affected by the injurer's care choice, but it is influenced by his activity level—the more active he is, the more piggyback suits he will potentially face, which raises his expected costs regardless of which type of equilibrium obtains.

Given the foregoing results, the following proposition compares the injurer's care and activity choices to those in the above certainty model: 
Proposition 1: (a) When the equilibrium under uncertainty is Type 1, the injurer chooses the same level of care, but a lower activity level, compared to the certainty model; (b) When the equilibrium under uncertainty is Type 2, the injurer chooses a higher level of care and a lower activity level compared to the certainty model.

Proof: For part (a), a comparison of (3) and (17) immediately shows that $x_{c}=x_{1}{ }^{*}$, while a comparison of (4) and (19) shows that $z_{c}>z_{1} *$. For part (b), a comparison of (3) and (18) shows that $x_{c}<x_{2}^{*}$, while a comparison of (4) and (20) shows that $z_{c}>z_{2}^{*}$.

The intuition for these results is as follows. When the equilibrium under uncertainty is Type 1, the injurer chooses the same level of care as under certainty because, although all potential piggyback plaintiffs successfully file suit and receive a positive settlement, the number of such suits is viewed by the injurer as fixed and hence independent of his choice of care. In contrast, the injurer chooses a lower activity level compared to the certainty model because the number of piggyback suits is positively related to his activity. But, when the equilibrium is of Type 2, the injurer chooses more care than in the certainty model because some cases go to trial, which involves higher costs than settlement. He also chooses a lower activity level than in the certainty model for the same reason. Generally speaking, therefore, the possibility of piggyback suits induces injurers to take either the same or more care, and to be less active, compared to a world without such suits. These results suggest that the potential success of piggyback suits generally increases deterrence of injurers (though it remains to be seen whether or not this is welfare-enhancing). 
Further insight can be gained by examining how variation in $q$ affects the type of equilibrium that emerges. Note first that (15) implies $\frac{\partial \hat{x}(q)}{\partial q}<0$. Further, $\hat{x}(q)$ gets large as $q$ approaches zero, and gets small as $q$ approaches infinity. Thus, given finite $x_{1}{ }^{*}$ and $x_{2}{ }^{*}$, all three of the above cases exist for different values of $q$, as shown by the lower panel in Figure 5.

Specifically, Case 1 is relevant for small $q$, Case 2 is relevant for intermediate $q$, and Case 3 is relevant for large $q$. As for the type of equilibrium that obtains, note that the minimized value of the injurer's care-plus-settlement costs under a Type 1 equilibrium, denoted $T C_{1}{ }^{*}$, is increasing in $q$, while his corresponding costs under a Type 2 equilibrium, $T C_{2}{ }^{*}$, is independent of $q$. Thus, the progression from Figure 1 through Figure 4 occurs as $q$ increases, with the injurer's Type 1 cost curve rising with $q$ while his Type 2 cost curve remains fixed. As a result, the switch from a Type 1 to a Type 2 equilibrium occurs in the range described by Case 2, as shown in the upper panel of Figure 5, which graphs $T C_{1} *(q)$ and $T C_{2} *$. Intuitively, as the potential number of piggyback suits increases, the defendant is more willing to go to trial so as not to have to settle with them.

[Figure 5 here]

\section{Welfare Analysis}

This section evaluates the effect of piggyback suits on social welfare as measured by the expected value of the injurer's activity less total expected accident costs, including litigation costs. ${ }^{14}$ The benchmark is the level of care and activity that a social planner would choose, assuming that the planner can perfectly distinguish between legitimate and piggyback suits. In

\footnotetext{
${ }^{14}$ On the general question of how lawsuits affect welfare, see Shavell (1982) and Polinsky and Rubinfeld (1988). The first-best outcome in which the expected value of the activity is maximized and no litigation costs are incurred is not attainable in this model since injurers will only internalize accident costs if victims file suit under strict liability. But see the discussion of negligence in Section 6.1.
} 
this context, only legitimate plaintiffs would file suit, and all would settle, as in the certainty model above. Thus, the planner's problem is to solve

$$
\max _{x, z} V(z)-z[x+p(x)(L+k)]
$$

which yields the following first-order conditions for $x$ and $z$ :

$$
\begin{aligned}
& 1+p^{\prime}(x)(L+k)=0, \\
& V^{\prime}(z)-[x+p(x)(L+k)]=0 .
\end{aligned}
$$

Denote the solutions to these conditions $x^{*}$ and $z^{*}$.

Based on these results we first state

Proposition 2: In the certainty model where no frivolous suits are filed, the injurer underinvests in care and over-engages in the activity.

Proof: Comparison of (3) and (4) with (22) and (23) immediately shows that $x^{*}>x_{c}$ and $z^{*}<z_{c}$.

This is true, first, because the injurer ignores the victim's filing cost, $k$, and second, because in settlement bargaining the injurer ends up paying less than the victim's actual damages by an amount equal to the latter's cost of trial. ${ }^{15}$ This result verifies the conventional view that when litigation is costly, strict liability underdeters. ${ }^{16}$

Now consider how the injurer's equilibrium care and activity levels in the model under uncertainty compare to the socially optimal choices as defined by (22) and (23):

\footnotetext{
${ }^{15}$ This latter effect is obviously a consequence of the assumption that the defendant makes a take-it-or-leave-it offer equal to the minimum amount the plaintiff is willing to accept (i.e., the defendant captures all of the surplus from pre-trial bargaining).

${ }^{16}$ In a more general model in which harm varies across plaintiffs, victims with low damages would be discouraged from filing suit, which would further reduce deterrence relative to the social optimum.
} 
Proposition 3: (a) When the equilibrium is Type 1, the injurer takes too little care, but may choose either too much or too little activity compared to the social optimum; (b) When the equilibrium is Type 2, the injurer may take too much or too little care, and may choose too much or too little activity level compared to the social optimum.

Proof: For part (a), a comparison of (17) and (22) shows that $x_{1}^{*}<x^{*}$, while a comparison of (19) and (23) shows that $z_{1} * \frac{\geq}{<} z^{*}$. For part (b), a comparison of (18) and (22) shows that $x_{2} * \frac{\geq}{<} x^{*}$, while a comparison of (20) and (23) shows that $z_{2} * \frac{\geq}{<} z^{*}$.

When the equilibrium under uncertainty is a Type 1, the injurer's care choice is the same as in the certainty model (as shown in Proposition 1), and so, for reasons noted above, he takes too little care. As for his activity choice, he may over- or under-engage in activity. He may over-engage because he ignores the filing costs of victims, but he may under-engage because all potential piggyback plaintiffs file suit and settle, thus raising total settlement costs. When the equilibrium is Type 2, the injurer's care and activity levels both deviate from the social optimum and for the same reasons: while he ignores the victim's filing cost (causing care to fall and activity to rise), he faces trial costs because not all cases settle (causing care to rise and activity to fall). The direction of the deviation depends on the relative magnitudes of $k$ and $C_{d}$.

The results in this section show that the possible existence of piggyback suits generally has an ambiguous effect on the care and activity choices of the injurer. Depending on the equilibrium of the settlement game, piggyback suits may result in too much or too little care, and too much or too little activity, compared to what a planner would choose under conditions of 
certainty but costly litigation. These conclusions suggest that frivolous litigation is not necessarily detrimental to social welfare.

The reason for these somewhat surprising conclusions is as follows. On one hand, frivolous suits may lead to too much care and too little activity because injurers expect to face higher costs as a result of their existence. But on the other hand, frivolous suits "correct for" the fact that when litigation is costly, injurers ignore the trial and filing costs of plaintiffs. The amount of the "correction," however, is not related in any systematic way to the amount of underdeterrence, so as a general matter it is not possible to say whether frivolous suits improve or worsen welfare.

\section{Further considerations}

This section considers three extensions of the basic model: the use of negligence rather than strict liability, the impact of fee-shifting rules, and the effects of other legal mechanisms for deterring frivolous lawsuits.

\subsection{Negligence}

This section briefly discusses how the results would change under a well-functioning negligence rule with a due standard of $\bar{x} .{ }^{17}$ Note first that if the injurer complies with the negligence standard, no suits (either legitimate or frivolous) would be filed because all plaintiffs would expect to lose at trial. As a result, no litigation costs would be incurred, and the efficient level of injurer care, denoted $x^{* *}$, is that which minimizes $x+p(x) L$, where $x_{2}^{*}>x^{* *}>x_{1} *$.

In the certainty case, the injurer will comply with the due standard if

$$
\bar{x} \leq\left[x_{c}+p\left(x_{c}\right)\left(L-C_{p}\right)\right],
$$

\footnotetext{
${ }^{17}$ By "well-functioning," we mean that the court implements the rule without error (in contrast to Hylton (1990b)).
} 
where, recall that $x_{c}=x_{1} *$. Thus, if $\bar{x}$ is set at $x^{* *}>x_{c}$, the injurer may or may not find it optimal to comply. If he does, then the first-best (zero litigation cost) level of accident costs is achieved. However, because the injurer avoids suits by taking due care, he will choose $z$ to maximize

$$
V(z)-z \bar{x},
$$

which results in an excessively high level of activity (Shavell, 1980). Alternatively, if the injurer would not find it optimal to comply with a due standard set at $x^{* *}$, then $\bar{x}$ would have to be adjusted downward to the point where (24) holds in order to induce compliance. In that case, the injurer takes less than efficient care, but he continues to over-engage in the activity.

The outcome is basically the same in the uncertainty model, except that in this case, because two equilibria are possible, compliance requires that the following condition hold:

$$
\bar{x} \leq \min \left[x_{1}^{*}+\left(p\left(x_{1}^{*}\right)+q\right)\left(L-C_{p}\right), x_{2}^{*}+p\left(x_{2}^{*}\right)\left(L+C_{d}\right)\right] .
$$

Now, since $x_{2}^{*}>x^{* *}$, if a Type 2 equilibrium obtains, setting $\bar{x}=x^{* *}$ will always induce compliance, and the first-best level of care is achieved. However, if a Type 1 equilibrium obtains, compliance may or may not be possible with $\bar{x}=x^{* *}$ since $x_{1}^{*}>x^{* *}$. If it is not possible, $\bar{x}$ will have to be adjusted downward as described above for the certainty case. Either way, the injurer avoids all suits, including piggyback suits, and again chooses his activity level to maximize (25), resulting in excessive activity.

The arguments in this section establish the following result:

Proposition 4: Under a properly chosen negligence standard, (a) Injurers will comply with the due standard and no suits, either legitimate or frivolous, will be filed; (b) Injurers will either take efficient or too little care; and (c) Injurers will over-engage in the risky activity. 
The threat of frivolous suits therefore has no effect on deterrence under a well-functioning negligence rule because, given perfect compliance (as we have assumed), no suits of any kind are filed.

\subsection{Fee Shifting and Other Corrective Policies}

Proponents of litigation reform often suggest that a switch to the English rule for allocating legal costs would discourage frivolous suits. This section examines the impact of the English rule in the context of the current model, and then extends the logic to Rule 11 sanctions.

Note first that the minimum amount a truly injured plaintiff would accept to settle under the English rule is $S=L+k$ since, if the plaintiff goes to trial and wins (which occurs with certainty under strict liability), she would incur no trial costs and her sunk filing costs would be reimbursed. In the certainty case, the defendant therefore offers zero to all frivolous plaintiffs, who drop their cases, and settles with all truly injured plaintiffs for $L+k$. The resulting expected cost for injurers is

$$
V(z)-z[x+p(x)(L+k)],
$$

which coincides with net social benefits in (21). This immediately implies

Proposition 5: Under the certainty model, the English rule for allocating legal costs results in efficient care and activity by injurers.

Under uncertainty, the defendant's choice under the English rule is between offering $S=L+k$ and $S=0$. After working through the model as above, we find that if the following condition holds

$$
\frac{p(x)}{p(x)+q}>\frac{L+k}{L+C_{p}+C_{d}+k},
$$


a Type 1 (pure strategy) equilibrium exists under which the defendant settles with all plaintiffs $(\theta=1)$ and all piggyback plaintiffs file $(\varphi=1)$. Alternatively, if

$$
\frac{p(x)}{p(x)+q}<\frac{L+k}{L+C_{p}+C_{d}+k}
$$

a Type 2 (mixed strategy) equilibrium exists, where the probability that the defendant offers $S=L+k$ rather than $S=0$ is

$$
\theta^{*}=\frac{k}{L+k}
$$

and the probability that a piggyback plaintiff files suit is

$$
\varphi^{*}=\frac{p(x)\left(C_{p}+C_{d}\right)}{q(L+k)} .
$$

The resulting costs for the defendant under the two equilibria are

$$
\begin{aligned}
& T{C_{1}}^{\mathrm{E}}=x+[p(x)+q](L+k) \\
& T{C_{2}}^{\mathrm{E}}=x+p(x)\left(L+C_{p}+C_{d}+k\right) .
\end{aligned}
$$

Based on these costs, we first compare the equilibrium outcomes under the American and English rules:

Proposition 6: A switch from the American rule to the English rule results in more care and less activity by the injurer under both types of equilibria.

Proof: A comparison of (32) and (10) shows that $x_{1}{ }^{\mathrm{E}}>x_{1} *$ and $z_{1}{ }^{\mathrm{E}}<z_{1} *$ for the Type 1 equilibrium; and comparison of (33) and (12) shows that $x_{2}{ }^{\mathrm{E}}>x_{2} *$ and $z_{2}{ }^{\mathrm{E}}<z_{2} *$ for the Type 2 equilibrium.

We next consider how the English rule affects welfare: 
Proposition 7: Under the English rule for allocating legal costs: (a) When the equilibrium is Type 1, injurers invest in efficient care, and choose too little activity; and (b) when the equilibrium is Type 2 , injurers invest in too much care, and choose too little activity.

Proof: (a) The first order condition for $x$ from (32) is $1+p^{\prime}(x)(L+k)=0$, which is identical to (22), implying that $x_{1}{ }^{\mathrm{E}}=x^{*}$. Comparison of (32) and (21) shows that the marginal cost of $z$ is higher under the English rule in this equilibrium, implying that $z_{1}{ }^{\mathrm{E}}<z^{*}$; (b) The first order condition for $x$ from (33) is $1+p^{\prime}(x)\left(L+C_{p}+C_{d}+k\right)=0$. Compared to (22), this shows that $x_{2}{ }^{\mathrm{E}}>x^{*}$. Comparison of (33) and (21) shows that the marginal cost of $z$ is higher under the English rule in this equilibrium as well, implying that $z_{2}{ }^{\mathrm{E}}<z^{*}$

The English rule thus results in either efficient or excessive care, and too little activity from a social point of view. This suggests that a switch from the American to the English rule is not necessarily conducive to greater social welfare.

Rule 11 sanctions provide for the imposition of monetary sanctions on plaintiffs who file a pleading, written motion, or other paper with the court that is "presented for any improper purpose, such as to harass, cause unnecessary delay, or needlessly increase the cost of litigation."18 The usual sanction is the awarding of reasonable legal fees to the defendant. Rule 11 thus differs from the English rule in that fee shifting depends not only on who wins the case, but also on the court's assessment of the strength of the case. However, since we have assumed here that the court can perfectly discern frivolous from legitimate suits, and that all legitimate plaintiffs win at trial (under a strict liability rule), then the effect of the threat of Rule 11

\footnotetext{
${ }^{18}$ Federal Rules of Civil Procedure, Rule 11(b)(1).
} 
sanctions in the current model would be effectively identical to a switch to the English rule, and would therefore have the same implications for injurer care and activity. ${ }^{19}$

\subsection{Other Mechanisms for Deterring Frivolous Suits}

At the federal level, attorneys are personally liable for costs, expenses, and attorney's fees arising from unreasonable or vexatious conduct under 28 U.S.C. $§ 1927 .^{20}$ In addition, attorneys have a bar-level ethical obligation to refrain from filing frivolous lawsuits. ${ }^{21}$ Failure to comply with this ethical rule may lead to attorney discipline, including the possibility of disbarment. This professional risk provides an additional avenue, alongside cost-shifting rules, for discouraging attorneys from accepting frivolous suits. In terms of the model, the imposition of personal and professional liability on attorneys is specifically aimed at reducing $q$, the fraction of piggyback suits in the population of plaintiffs facing a given defendant.

A second policy aimed at reducing $q$ is to directly discourage piggyback plaintiffs by "naming and shaming" filers of frivolous lawsuits. A few states have enacted statutes that make the names of vexatious litigants publicly available (for instance, via the internet), and to impose extra burdens on these litigants when they seek to file a lawsuit. For example, since 1991, California has maintained a Vexatious Litigant List, which lists those plaintiffs who satisfy at least one of several statutorily identified criteria, such as filing repeated frivolous motions or pleadings. Texas has likewise enacted legislation under its Civil Practice and Remedies Code,

\footnotetext{
${ }^{19}$ For more general treatment of the economic impact of Rule 11 sanctions, see Polinsky and Rubinfeld (1993) and Bebchuk and Chang (1996).

${ }^{20}$ Specifically, 28 U.S.C. $§ 1927$ reads, “[an] attorney or other person admitted to conduct cases in any court of the United States or any Territory thereof who so multiplies the proceedings in any case unreasonably and vexatiously may be required by the court to satisfy personally the excess costs, expenses, and attorney's fees reasonably incurred because of such conduct." See Pollack (1977, pp. 623-629) for an examination of the elements required to satisfy this statute.

${ }^{21}$ See generally 7 Am Jur 2d Attorneys at Law $§ 46$.
} 
which requires vexatious litigants to obtain permission, and to post security, before filing suit. A number of other states have enacted similar laws. ${ }^{22}$

As shown above (see Figure 5), the effect on the basic model (American rule and strict liability) of an exogenous reduction in $q$ is to cause the equilibrium to approach the certainty outcome (which corresponds to $q=0$ ). Specifically, $\hat{x}(q)$ increases as $q$ falls, given $\partial \hat{x} / \partial q<0$, which makes the Type 1 equilibrium, in which all cases settle, more likely. Based on Proposition 2 above, we know that injurers are underdeterred in the certainty case, and based on Proposition 3, they may be over- or underdeterred under uncertainty. Thus, we have

Proposition 8: Policies aimed at reducing the proportion of piggyback suits in the population of all suits may or may not increase social welfare.

This conclusion further illustrates the ambiguity surrounding the effect of frivolous lawsuits on social welfare in a costly legal system.

\section{Conclusion}

Frivolous lawsuits are nearly universally decried as a source of inefficiency in the civil justice system. However, the analysis in this paper has shown that the question of how frivolous litigation affects social welfare is a complex one that does not admit a clear answer. Part of the problem is defining exactly what constitutes a "frivolous" suit, but beyond that semantic issue is the incentive structure of the liability system, which relies on costly lawsuits to create incentives for those engaged in risky activities to avoid accidents. A large literature has arisen to show that once litigation costs are included in accident models, the social and private incentives to sue will

\footnotetext{
${ }^{22}$ These include Florida, Nevada, Ohio, and Utah.
} 
not generally coincide, possibly resulting in too many or too few suits. The conclusions in this paper are in line with that reasoning.

The fact that frivolous suits may, in some circumstances, improve welfare should not, however, be interpreted as a justification for curbing efforts to discourage meritless cases. First of all, it is not possible to state as a general matter when frivolous suits are welfare-enhancing and when they are welfare-reducing. But more importantly, the perception that frivolous litigation is widespread undermines confidence that the legal system functions well as a social institution aimed at promoting justice and social order. As a matter of public policy, we suspect that this factor would overwhelm any of the considerations raised in this paper. 


\section{References}

Bebchuk, Lucian A. 1988. Suing Solely to Extract a Settlement Offer. Journal of Legal Studies 17: 437-450.

1998. Suits with Negative Expected Value. The New Palgrave Dictionary of Economics and the Law 3: 551-554.

1996. A New Theory concerning the Credibility and Success of Threats to Sue. Journal of Legal Studies 25(1): 1-25.

Bebchuk, Lucian A. \& Howard F. Chang. 1996. An Analysis of Fee Shifting Based on the Margin of Victory: On Frivolous Suits, Meritorious Suits, and the Role of Rule 11. Journal of Legal Studies 25: 371-403

Bone, Robert G. 1997. Modeling Frivolous Suits. University of Pennsylvania Law Review 145: 519-605.

Hylton, Keith. 1990a. The Influence of Litigation Costs on Deterrence Under Strict Liability and Under Negligence. International Review of Law and Economics 10: 161-171.

1990b. Costly Litigation and Legal Error Under Negligence. Journal of Law, Economics, and Organization 6: 433-452.

Katz, Avery. 1990. The Effect of Frivolous Lawsuits on the Settlement of Litigation. International Review of Law and Economics 10: 3-27.

Miceli, Thomas J. 1994. Do Contingent Fees Promote Excessive Litigation? Journal of Legal Studies 23: 211-224.

1993. Optimal Deterrence of Nuisance Suits by Repeat Defendants. International Review of Law and Economics 13: 135-144.

Ordover, Janusz. 1978. Costly Litigation in the Model of Single Activity Accidents. Journal of Legal Studies 7: 243-261.

Polinsky, A. Mitchell \& Daniel L. Rubinfeld. 1993. Sanctioning Frivolous Suits: An Economic Analysis. Georgetown Law Journal 82: 397-435.

1988. The Welfare Implications of Costly Litigation for the Level of Liability. Journal of Legal Studies 17: 151-164.

Pollack, David W. 1977. Comment: Sanctions Imposed by Courts on Attorneys Who Abuse the Judicial Process. University of Chicago Law Review 44: 619-640. 
Rasmusen, Eric B. 1998. Nuisance Suits. The New Palgrave Dictionary of Economics and the Law 2: 690-693.

Rosenberg, David \& Steven Shavell. 1985. A Model in Which Suits Are Brought for Their Nuisance Value. International Review of Law and Economics 5: 3-13.

Shavell, Steven. 1985. Uncertainty over Causation and the Determination of Civil Liability. Journal of Law and Economics 28: 587-609. 1982. The Social versus Private Incentive to Bring Suit in a Costly Legal System. Journal of Legal Studies 11: 333-339. 1980. Strict Liability versus Negligence. Journal of Legal Studies 9: 1-25. 


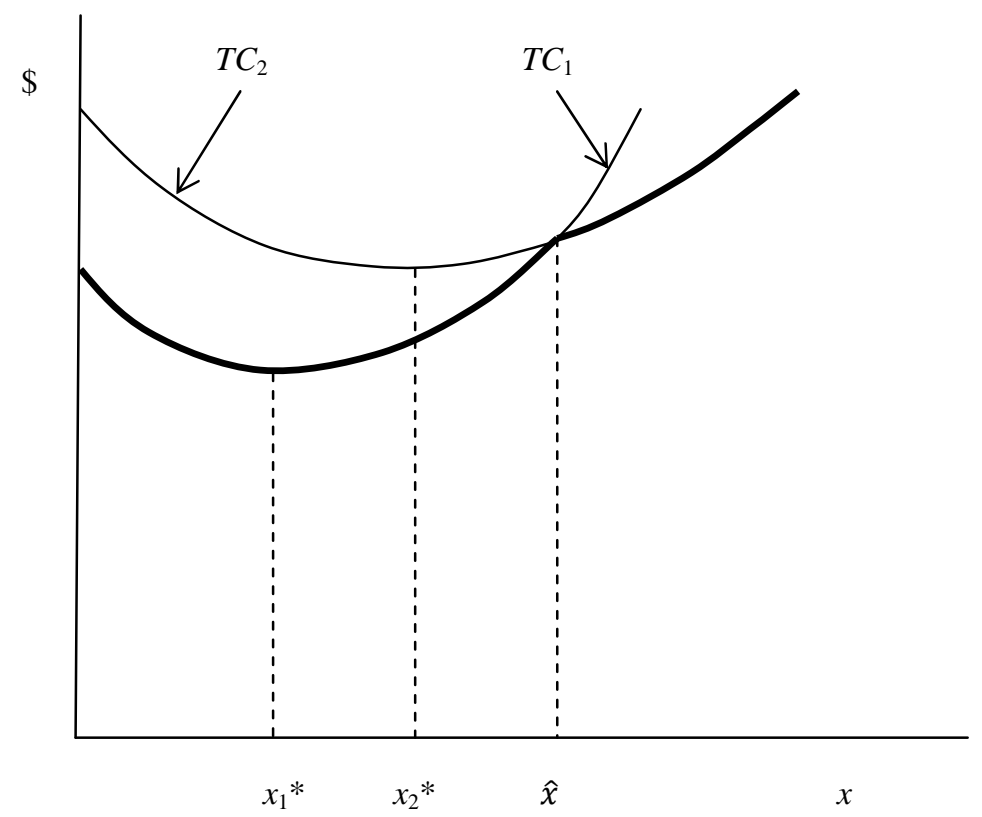

Figure 1. Injurer's optimal care choice in Case 1. 


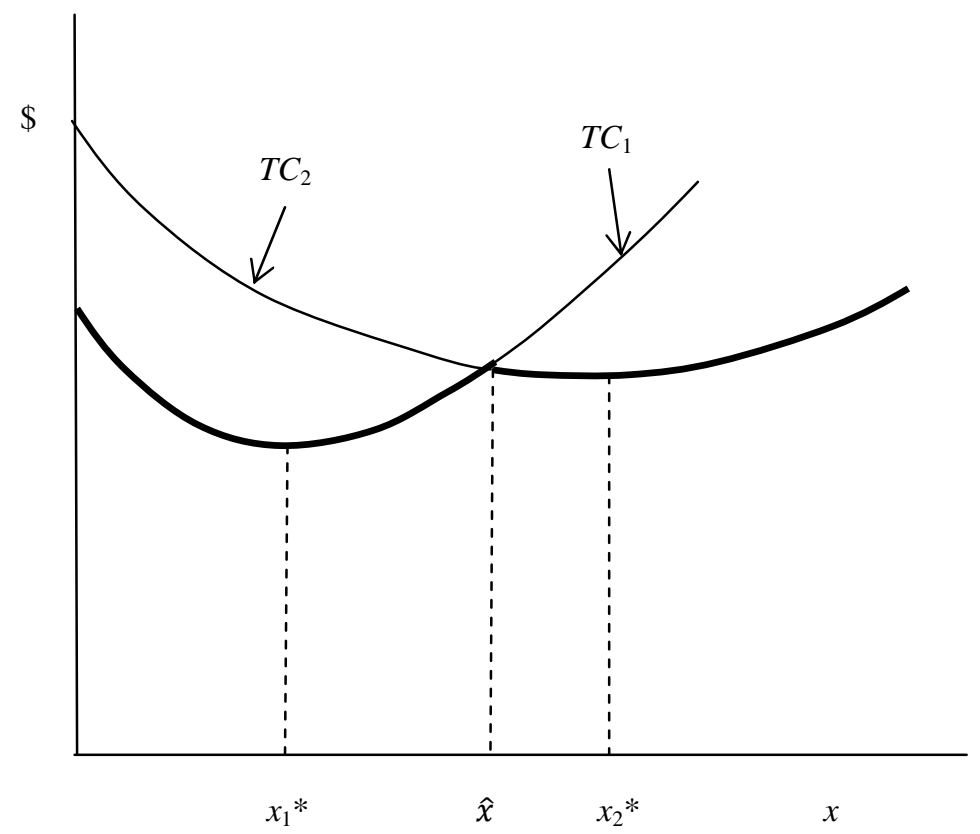

Figure 2. Injurer's optimal care choice in Case 2 (a). 


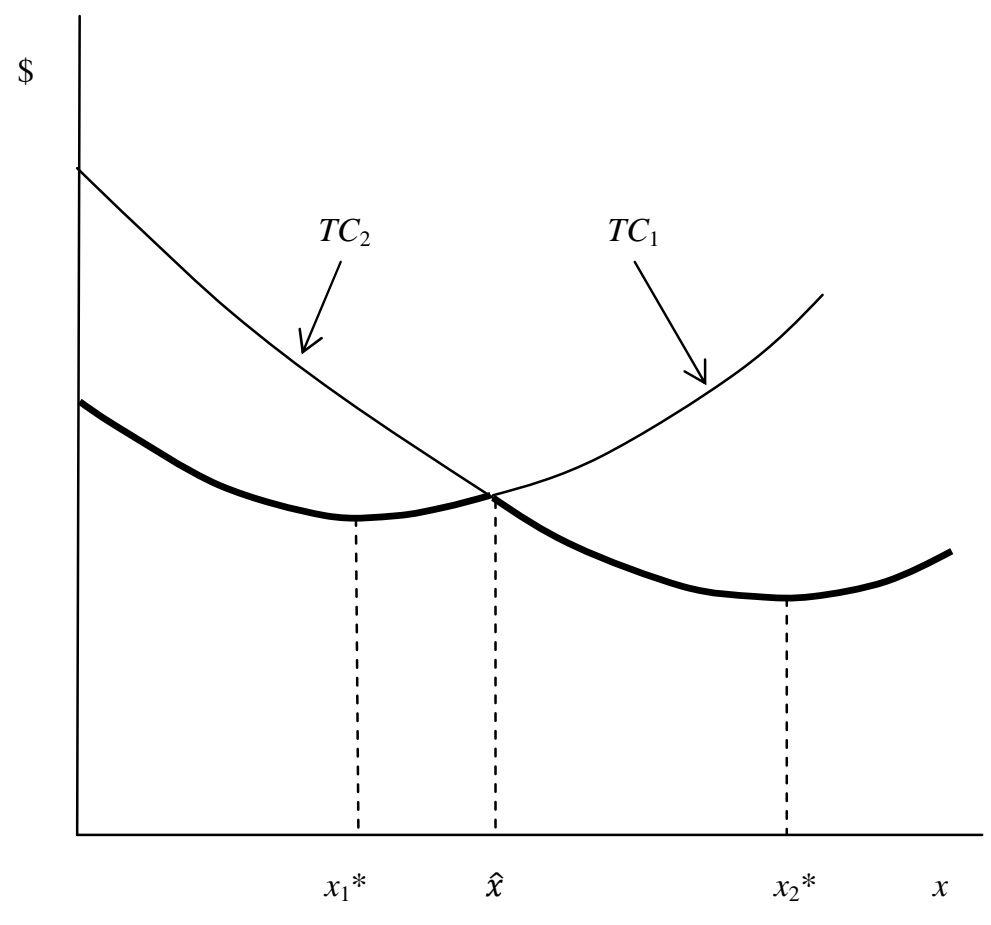

Figure 3. Injurer's optimal care choice in Case 2 (b). 


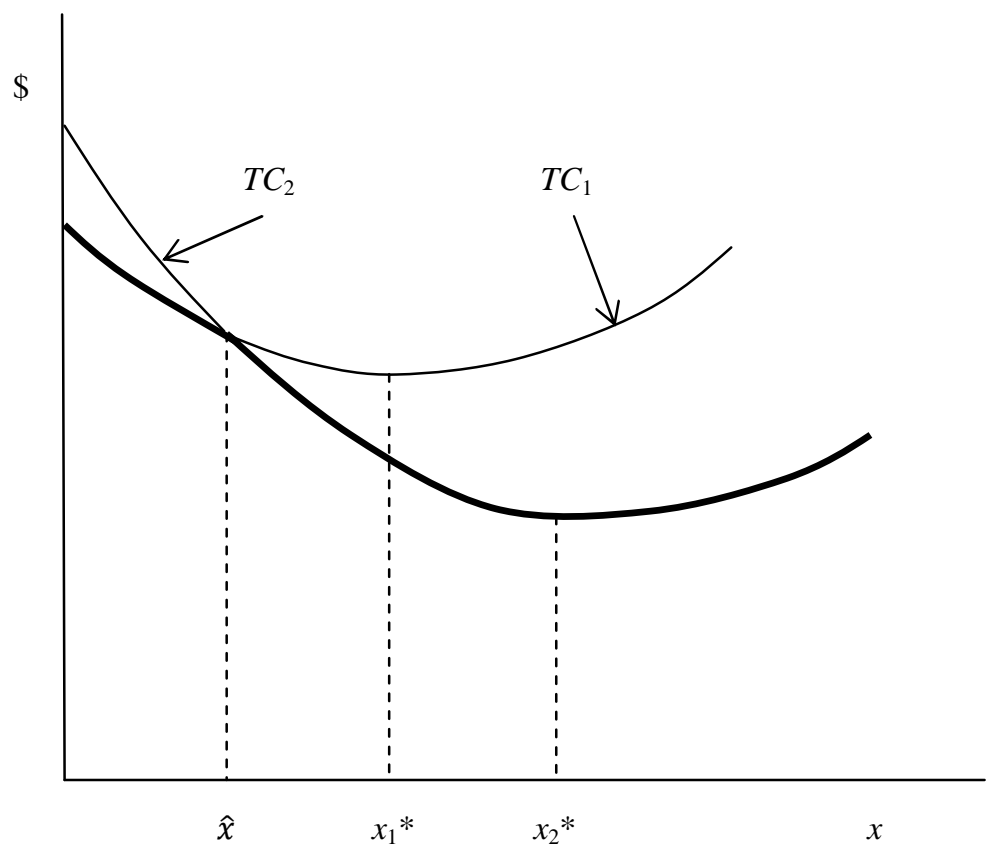

Figure 4. Injurer's optimal care choice in Case 3. 


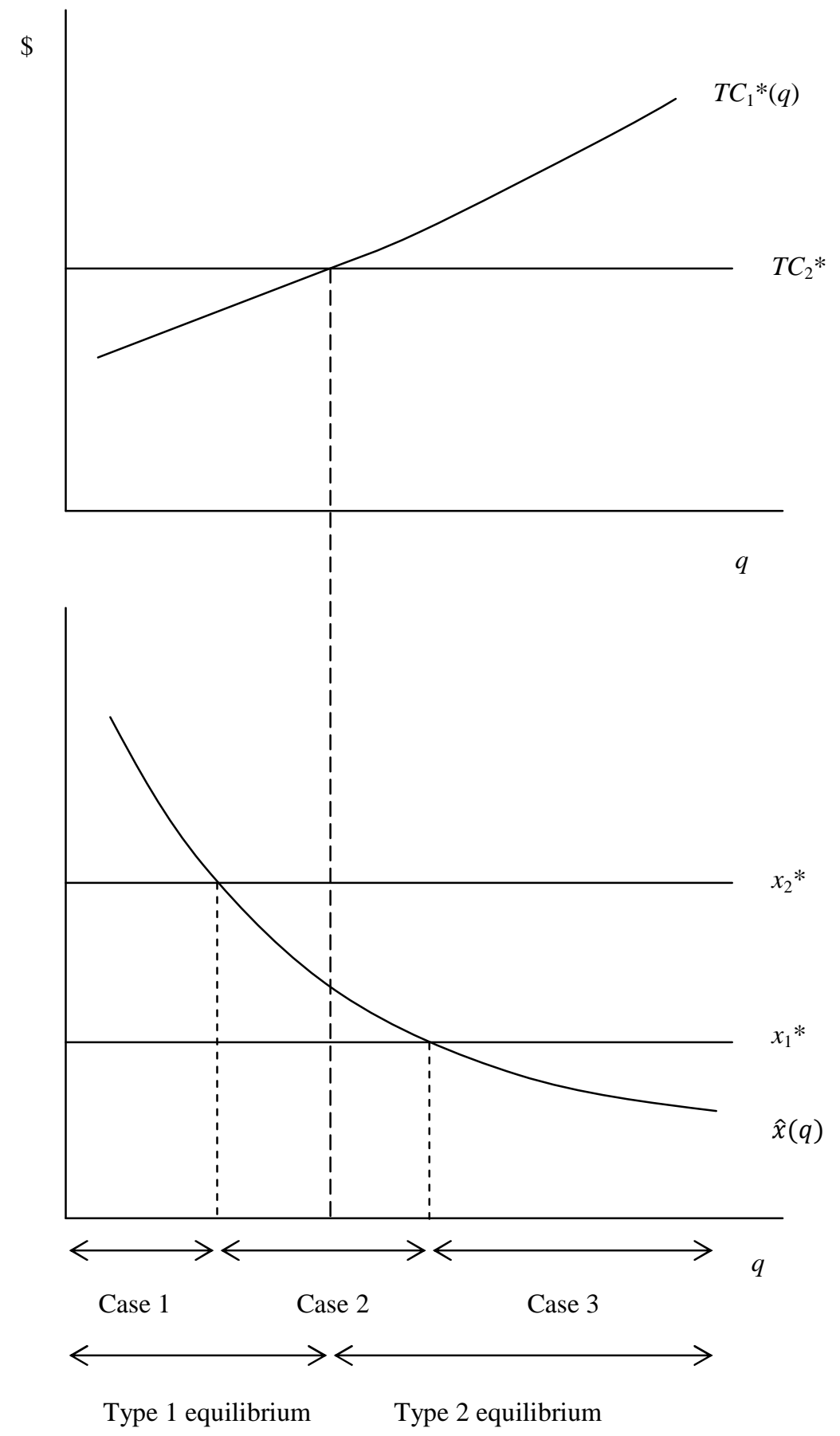

Figure 5. The effect of $q$ on which equilibrium obtains under uncertainty. 